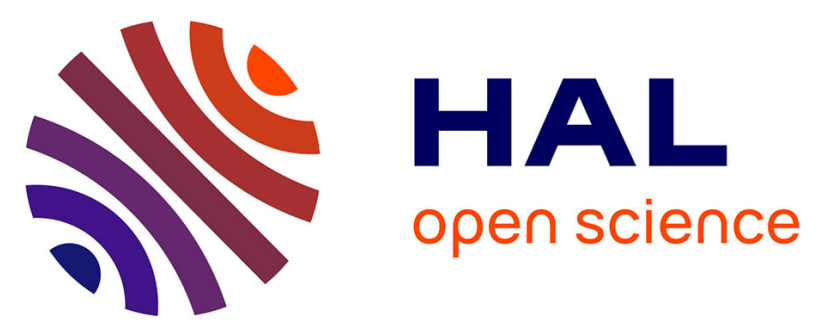

\title{
Owariensisone: a new iridolactone from the whole plant of Brillantaisia owariensis P. Beauv
}

\author{
Perrin Lanversin Foning Tebou, Florence Déclaire Mabou, David Ngnokam, \\ Dominique Harakat, Laurence Voutquenne-Nazabadioko
}

\section{- To cite this version:}

Perrin Lanversin Foning Tebou, Florence Déclaire Mabou, David Ngnokam, Dominique Harakat, Laurence Voutquenne-Nazabadioko. Owariensisone: a new iridolactone from the whole plant of Brillantaisia owariensis P. Beauv. Natural Product Research, 2016, 30 (14), pp.1611-1616. 10.1080/14786419.2015.1126265 . hal-01996505

\section{HAL Id: hal-01996505 \\ https://hal.univ-reims.fr/hal-01996505}

Submitted on 26 Nov 2021

HAL is a multi-disciplinary open access archive for the deposit and dissemination of scientific research documents, whether they are published or not. The documents may come from teaching and research institutions in France or abroad, or from public or private research centers.
L'archive ouverte pluridisciplinaire HAL, est destinée au dépôt et à la diffusion de documents scientifiques de niveau recherche, publiés ou non, émanant des établissements d'enseignement et de recherche français ou étrangers, des laboratoires publics ou privés.

\section{(ㅇ)(1) $\$$}

Distributed under a Creative Commons Attribution - NonCommerciall 4.0 International 


\title{
Owariensisone: a new iridolactone from the whole plant of Brillantaisia owariensis P. Beauv
}

\author{
Perrin Lanversin Foning Tebou ${ }^{a}$, Florence Déclaire Maboua, David Ngnokamª, \\ Dominique Harakat ${ }^{b}$ and Laurence Voutquenne-Nazabadioko ${ }^{c}$
}

aFaculty of Science, Department of Chemistry, University of Dschang, Dschang, Cameroon; bService Commun d'Analyses, Institut de Chimie Moléculaire de Reims (ICMR), CNRS UMR 7312, Reims, France; ' ${ }^{C}$ roupe Isolement et Structure, Institut de Chimie Moléculaire de Reims (ICMR), CNRS UMR 7312, Reims, France

\begin{abstract}
From the whole plant of Brillantaisia owariensis P. Beauv, a new iridolactone, owariensisone (1) together with six known compounds (nepetin-7-O-glucoside, choline, sucrose, mannitol, xylitol, 1-Opalmitoyl-2-eicosanoyl-3-O-(6-amino-6-deoxy)- $\beta$-D-glucopyranosylglycerol) were isolated. Structures of these compounds were established by direct interpretation of their spectral data, mainly HR-TOFESIMS, 1-D NMR $\left({ }^{1} \mathrm{H}\right.$ and $\left.{ }^{13} \mathrm{C}\right)$ and 2-D NMR $\left({ }^{1} \mathrm{H}-{ }^{1} \mathrm{H}\right.$ COSY, HSQC, HMBC, NOESY, TOCSY and DOCSY) and by comparison with the literature.
\end{abstract}

\section{KEYWORDS}

Brillantaisia owariensis;

Acanthaceae; owariensisone;

structure elucidation

\section{Introduction}

Brillantaisia owariensis P. Beauv (Acanthaceae) is a large erect shrub with purple-blue flowers (Heine, 1963). It is found growing throughout tropical Africa and Madagascar. The leaves of this plant are used in Democratic Republic of Congo folk medicine for the treatment of anaemia (Ngbolua et al. 2013). Previous studies on this species have revealed the presence of sesquiterpene glycoside (Asai et al. 2012). In our continuous search for potentially interesting novel and bioactive secondary metabolites from Cameroonian medicinal plants (Djouossi et al. 2014; Mabou et al. 2014), we have examined the methanol extract of the whole plant 

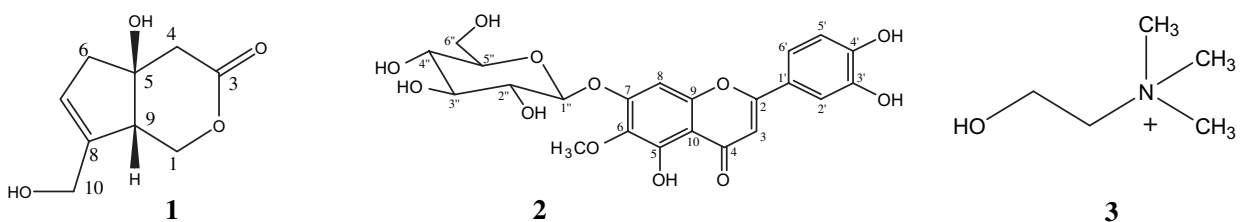

2

3

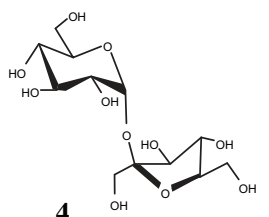

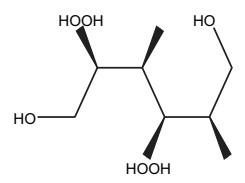

5

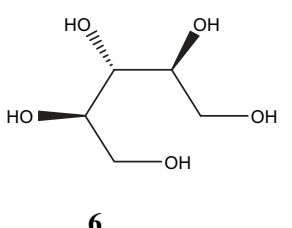

6

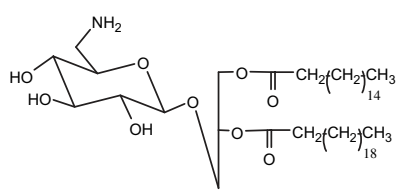

7

Figure 1. Structures of the isolated compounds (1-7).

of Brillantaisias owariensis. In the present paper, we report the isolation of new iridolactone, owariensisone (1) together with six known compounds (Figure 1), from the crude methanol extract of the whole plant.

\section{Results and discussion}

Compound 1 was obtained as a yellowish gum. Its HR-TOFESIMS exhibited a pseudomolecular ion peak at $\mathrm{m} / \mathrm{z} 207.0631[\mathrm{M}+\mathrm{Na}]^{+}$(Calcd for $\mathrm{C}_{9} \mathrm{H}_{12} \mathrm{O}_{4} \mathrm{Na}$ 207.0633) consistent with a molecular formula $\mathrm{C}_{9} \mathrm{H}_{12} \mathrm{O}_{4}$ and indicating four degrees of unsaturation.

The ${ }^{1} \mathrm{H}-\mathrm{NMR}$ spectrum showed one olefinic proton at $\delta_{\mathrm{H}} 5.68\left(\mathrm{H}-7, \mathrm{brq}^{\mathrm{t}} \mathrm{d}, J=1.8 \mathrm{~Hz}\right)$, two methylenic protons at $\delta_{\mathrm{H}} 2.59$ and $2.64(\mathrm{H}-6 \mathrm{a}$ and $\mathrm{H}-6 \mathrm{~b})$, and $\delta_{\mathrm{H}} 2.79$ and $2.82(\mathrm{H}-4 \mathrm{a}$ and $\mathrm{H}-4 \mathrm{~b})$, two oxymethylenic protons at $\delta_{\mathrm{H}} 4.12\left(2 \mathrm{H}, \mathrm{H}-10\right.$, brs) and $\delta_{\mathrm{H}} 4.24$ and $4.58(\mathrm{H}-1 \alpha$ and $\mathrm{H}-1 \beta)$ and one methinic proton at $\delta_{\mathrm{H}} 3.02(\mathrm{H}-9, \mathrm{t}, J=5.3 \mathrm{~Hz})$ attributed to the boschnialactone type skeleton (Sakan et al. 1967; Sisido et al. 1968; Callant et al. 1983; Bianco 1990; Tanaka et al. 1993; Hilgraf et al. 2012). This was supported by its ${ }^{13} \mathrm{C}$-NMR spectrum exhibiting nine carbon signals including one ester carbonyl at $\delta_{\mathrm{C}} 174.6(\mathrm{C}-3)$, two ethylenic carbons at $\delta_{\mathrm{C}} 141.7(\mathrm{C}-8)$ and 126.9 (C-7), four methylene carbons at $\delta_{C} 68.6$ (C-1), 60.5(C-10), 48.0 (C-6) and 44.5 (C-4), one methine carbon at $\delta_{\mathrm{C}} 55.1$ (C-9) and one quaternary carbon at $\delta_{\mathrm{C}} 80.0$ (C-4) bearing an hydroxy group. The ${ }^{1} J_{C-H}$ correlation in the HSQC spectrum allowed us to attribute to each carbon the corresponding proton. Thus, the two methylenic protons at $\delta_{\mathrm{H}} 2.59$ and 2.64 $(\mathrm{H}-6)$ and 2.79 and $2.82(\mathrm{H}-4)$ were linked to carbon $\mathrm{C}-6$ and $\mathrm{C}-4$ on the one hand, and the two oxymethylenic protons at $\delta_{\mathrm{H}} 4.24$ and $4.58(\mathrm{H}-1)$ and $4.12(\mathrm{H}-10)$ were linked to carbon $\mathrm{C}-1$ and $\mathrm{C}-10$ on the another.

In the COSY spectrum, protons at $\delta_{\mathrm{H}} 2.59$ and $2.64(\mathrm{H}-6 \mathrm{a}$ and $\mathrm{H}-6 \mathrm{~b})$ were correlated with proton at $\delta_{\mathrm{H}} 5.68(\mathrm{H}-7)$ as well as protons at $\delta_{\mathrm{H}} 4.24$ and $4.58(\mathrm{H}-1 \mathrm{a}$ and $\mathrm{H}-1 \mathrm{~b})$ and proton at $\delta_{\mathrm{H}} 3.02(\mathrm{H}-9, \mathrm{t}, J=5.3 \mathrm{~Hz})$.

From the $\mathrm{HMBC}$ spectrum, correlation was observed between the proton at $\delta_{\mathrm{H}} 4.12(\mathrm{H}-10)$ and carbon at $\delta_{\mathrm{C}} 141.7$ (C-8), and 126.9 (C-7) suggesting that the oxymethylene was located at C-8. This spectrum also exhibited cross peaks between a proton at $\delta_{\mathrm{H}} 5.68(\mathrm{H}-7)$ with carbon at $\delta_{\mathrm{C}} 55.1(\mathrm{C}-9), 80.0(\mathrm{C}-5)$ and $48.0(\mathrm{C}-6)$, while the protons at $\delta_{\mathrm{H}} 2.79$ and $2.82(\mathrm{H}-4)$ showed correlations with carbons at $\delta_{\mathrm{C}} 174.6$ (C-3), 80.0 (C-5), 55.1 (C-9) and 48.0 (C-6).

The crucial step in the biosynthesis of all cyclic terpenes is the cyclisation step that gives rise to the individual ring systems. In all kingdoms of life, this step has 

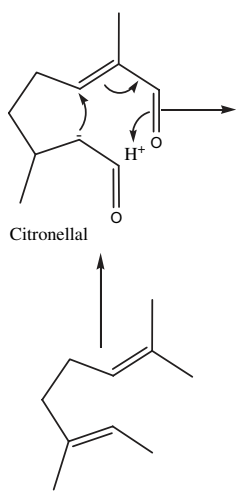
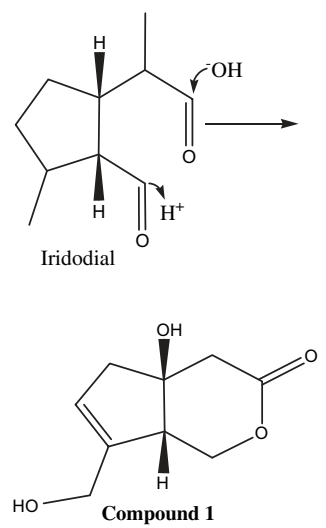
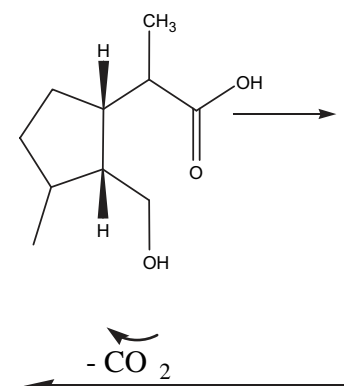
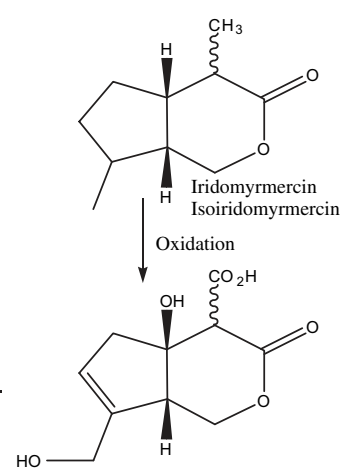

Figure 2. Tentative biosynthetic pathway for compound $\mathbf{1}$.

been shown to be catalysed by terpene cyclases, which are terpene synthases that use polyprenyl diphosphates cyclases, such as geranyl diphosphate to produce a cationic species that is subsequently cyclised and rearranged to form one of hundreds of possible ring structures (Degenhardt et al. 2009; Chen et al. 2011). However, the cyclisation step that leads to the characteristic 5-6 bicyclic scaffold of iridoids is markedly different. Feeding studies have suggested that the direct precursor of all iridoids in plants is not geranyl diphosphate, but the linear monoterpene 10-oxogeranial (Inouye et al. 1978; Uesato et al. 1983; Uesato, Matsuda, lida, et al. 1984; Uesato, Matsuda, Inouye 1984). Recently, Fernando and collaborators (2012) reported the discovery of iridoid synthase, a plant-derived enzyme that generates the iridoids ring scaffold; their results illustrate how a short-chain reductase was recruited as cyclase for the production of iridoids in medicinal plants. Therefore, the beta orientation of hydrogen at C-9 was supported by the biosynthetic pathway to iridomyrmercin and isoiridomyrmercin (Lunn 1961) and was further confirmed by the NOESY spectrum on which correlations were observed between $\mathrm{H}-9$ and $\mathrm{H}-10$ as well as $\mathrm{H}-7$ and $\mathrm{H}-10$. The stereochemistry at the $\mathrm{C}-5$ stereogenic was determined to be beta, due to the correlation observed in the NOESY spectrum between $\mathrm{H}-9$ and the proton of the hydroxyl group linked to this stereogenic carbon. The loss of the methyl group at C-4 undergoes probably through oxidation reaction (Figure 2). On the basis of aforementioned information, the structure of this compound was elucidated as lactone of $\alpha$-(2-hydromethyl-3-hydroxymethylcyclopent-3-en-yl) ethanoic acid named owariensisone (Figure 1 ).

Compounds 4, $\mathbf{5}$ and $\mathbf{6}$ were isolated as a mixture with the same retention factor (Rf) on the TLC plate and, TOCSY and DOCSY experiments were useful for determining their structures as sucrose (4) (Okada et al. 2010), mannitol (5) (Zhao et al. 2008) and xylitol (6) (Wang et al. 2013) (Figure 1). Structures of compounds 2, 3 and 7 (Figure 1) were also determined by means of spectroscopic data and by comparative analysis of their spectral data with those reported in the literature as known nepetin-7-O-glucoside (2) (Mohamed et al. 1983; Kenneth et al. 1988), choline (3) (Sarkar et al. 2009) and 1-O-palmitoyl-2-eicosanoyl-3-O-(6-amino-6-deoxy)- $\beta$-D-glucopyranosyl-glycerol (7) (He et al. 2006) (Figure 1). 


\section{Experimental}

\subsection{General}

Optical rotations were measured on a Perkin-Elmer 341 polarimeter. ${ }^{1} \mathrm{H}$ - and ${ }^{13} \mathrm{C}-\mathrm{NMR}$ spectra were recorded on a Bruker Avance III 600 spectrometer equipped with a cryo-platform $\left({ }^{1} \mathrm{H}\right.$ at $600 \mathrm{MHz}$ and ${ }^{13} \mathrm{C}$ at $150 \mathrm{MHz}$ ). 2-D NMR experiments were performed using standard Bruker microprograms (Xwin-NMR version 2.1 software). Chemical shifts $(\delta)$ are reported in parts per million (ppm) with the solvent signals as reference relative to TMS $(\delta=0)$ as internal standard, while the coupling constants ( $J$ values) are given in Hertz $(\mathrm{Hz})$. The IR spectra were recorded with a Shimadzu FT-IR-8400S spectrophotometer. UV spectra were determined as methanol solution with a Cary 50 UV/vis Spectrophotometer. HR-TOFESIMS experiments were performed using a Micromass Q-TOF micro instrument (Manchester, UK) with an electrospray source. The samples were introduced by direct infusion in a solution of $\mathrm{MeOH}$ at a rate of $5 \mu \mathrm{L} \mathrm{min}{ }^{-1}$. Column chromatography (CC) was performed on silica gel 60 (70-230 mesh, Merck) and gel permeation on Sephadex LH-20, while TLC was carried out on silica gel $\mathrm{GF}_{254}$ pre-coated plates with detection accomplished by spraying with $50 \%$ $\mathrm{H}_{2} \mathrm{SO}_{4}$ followed by heating at $100{ }^{\circ} \mathrm{C}$, or by visualising with an UV lamp at 254 and $365 \mathrm{~nm}$.

\subsection{Plant material}

The whole plant of Brillantaisia owariensis was collected at Tsinkop, Menoua Division, West Region of Cameroon, in October 2013. Authentication was done by Mr Victor Nana, a botanist of the Cameroon National Herbarium, Yaoundé, where the voucher specimen ( $N^{\circ} 34376 /$ HNC) has been deposited.

\subsection{Extraction and isolation}

The dried and powdered material $(4 \mathrm{~kg})$ was extracted with methanol $(3 \times 15 \mathrm{~L}, 72 \mathrm{~h})$ in a glass tank at room temperature affording $110 \mathrm{~g}$ of crude extract after evaporation of the solvent under vacuum.

A portion $(100 \mathrm{~g})$ of this crude extract was extracted with ethyl acetate to obtain after evaporation of solvent $60 \mathrm{~g}$ of EtOAc extract. Part of methanol-soluble extract $(8 \mathrm{~g})$ was subjected to silica gel CC eluting with gradient mixtures of EtOAc-MeOH $(5,10,20,30$ and $50 \%$ ). Many fractions, each $250 \mathrm{~mL}$, were collected and combined on the basis of their TLC profiles to give six sub-fractions noted F1-F6. Sub-fraction F1 $(1.1 \mathrm{~g})$ was passed through Sephadex LH-20 CC eluted with methanol and 25 fractions were collected. Fractions [15-25] (102 mg) were combined and purified on silica gel CC eluted with EtOAc-MeOH (98:2) to give compound 1 ( $8 \mathrm{mg})$. Sub-fraction F2 $(4.2 \mathrm{~g})$ was purified on silica gel CC eluted with EtOAc-MeOH (95:5) and many fractions (50 mL each) were collected. Fractions [21-40] (900 mg) were purified on silica gel CC, eluted with the same solvent system to afford the compounds (2) (10 mg) and (7) (5 mg). Fraction [50-100] (1.5 g) was purified on silica gel CC eluted with EtOAc-MeOH (15 and 20\%) and 35 sub-fractions (each, $25 \mathrm{~mL}$ ) were collected. The sub-fractions [5-6] (500 $\mathrm{mg}$ ) were repeatedly purified by CC over silica gel, eluted with EtOAc-MeOH (20\%) mixture to give the compound (3) $(10 \mathrm{mg})$ and the mixture of compounds (4), (5) and (6) (8 $\mathrm{mg})$. 


\subsection{New compound information}

\subsubsection{Owariensisone}

Yellowish gum. $[\alpha]_{\mathrm{D}}^{23}+2.6$ (c $\left.0.35 \mathrm{MeOH}\right)$. IR $(\mathrm{NaCl}) \nu_{\max }\left(\mathrm{cm}^{-1}\right): 3500,1740,1615 .{ }^{1} \mathrm{H}-\mathrm{NMR}$ $(600 \mathrm{MHz}) \delta_{\mathrm{H}}: 5.68\left(1 \mathrm{H}, \mathrm{brq}^{\mathrm{t}}, 1.8, \mathrm{H}-7\right), 4.58(1 \mathrm{H}, \mathrm{dd}, 11.8$ and $4.8, \mathrm{H}-1 \mathrm{~b}), 4.24(1 \mathrm{H}, \mathrm{dd}, 11.8$ and 6.6), 4.12 (2H, brs, H-10), $3.02(1 \mathrm{H}$, brt, 5.3, H-9), 2.82 (1H, d, 14.5, H-4b), $2.79(1 \mathrm{H}, \mathrm{d}, 14.5, \mathrm{H}-4 \mathrm{~b})$, $2.64(1 \mathrm{H}, \mathrm{dm}, 17.8, \mathrm{H}-6 \mathrm{~b})$ and $2.59(1 \mathrm{H}, \mathrm{dt}, 17.8,1.8, \mathrm{H}-6 \mathrm{a}) .{ }^{13} \mathrm{C}-\mathrm{NMR}(150 \mathrm{MHz}) \delta_{\mathrm{C}} .174 .6(\mathrm{C}-3)$, 141.7 (C-8), 126.9 (C-7), 80.0 (C-5), 68.6 (C-1), 60.5 (C-10), 55.1 (C-9), 48.0 (C-6) and 44.5 (C-4). HR-TOFESIMS m/z: $207.0631[\mathrm{M}+\mathrm{Na}]^{+}$(Calcd for $\mathrm{C}_{9} \mathrm{H}_{12} \mathrm{O}_{4} \mathrm{Na}$ 207.0633).

\section{Disclosure statement}

No potential conflict of interest was reported by the authors.

\section{References}

Asai T, Hirayama Y, Fujimoto Y. 2012. Epi- $\alpha$-bisabolol 6-deoxy- $\beta$-D-gulopyranoside from the glandular trichome exudate of Brillantaisia owariensis. Phytochem Lett. 5:376-378.

Bianco A. 1990. The chemistry of iridoids, in Atta-ur-Rhahman Ed. Stud Nat Prod Chem. 7:439-487.

Callant P, Storme P, Van der Eycken E, Vandewalle M. 1983. Iridoïds: stereospecific synthesis of functionalized cyclopentanoid intermediates via bicyclo [2.2.1] heptanones. Tetrahedron Lett. 24:5797-5800.

Chen F, Tholl D, Bohlmann J, Pichersky E. 2011. The family of terpene synthases in plants: a mid-size family of genes for specialized metabolism that is highly diversified throughout the kingdom. Plant J. 66:212-229.

Degenhardt J, Köllner TG, Gershenzon J. 2009. Monoterpene and sesquiterpene synthases and the origin of terpene skeletal diversity in plants. Phytochemistry. 70:1621-1637.

Djouossi MG, Foning TPL, Mabou FD, Ngnokam D, Tapondjou AL, Harakat D, Voutquenne-Nazabadioko L. 2014. Chevalierinoside A: a new isoflavonoid glycoside from the stem bark of Antidesma chevalieri Beille (Euphorbiaceae). Bull Chem Soc Ethiop. 28:309-314.

He ZD, Ma CY, Tan GT, Sydara K, Tamez P, Southavong B, Bouamanivong S, Soejarto DD, Pezzuto JM, Fong HH, Zhang HJ. 2006. Rourinoside and rouremin, antimalarial constituents from Rouera minor. Phytochemistry. 67:1378-1384.

Heine H. 1963. Flora of West tropical Africa, Vol. 2. Acanthaceae. 2nd ed. Hutchinson J, Dalziel JM, editors. London: Hepper, F. N. Millbank; pp. 391-425.

Hilgraf R, Zimmermann N, Lehmann L, Tröger A, Francke W. 2012. Stereoselective synthesis of trans-fused iridoïd lactones and their identification in the parasitoid wasp Alloxysta victrix, Part Il: Iridomyrmecins. Beilstein J Org Chem. 8:1256-1264.

Inouye H. 1978. Neuere Ergebnisse über die biosynthese der glucoside der iridoidreihe [New results about iridoids glucoside biosynthesis]. Planta Med. 33:193-216.

Kenneth RM, David RG. 1988. The major flavonoid of an antartic Bryum. Phytochemistry. 27:2843-2845. Lunn WH. 1961. Part I: the structure of catalposide Part II: carbonium ion formation at the C-10 position in 2,5-seco-A-bisnorcholestane structures [a thesis submitted to the Faculty of graduate studies and research in partial fulfilement of the requirements for the degree of Doctor of Philosophy]. Montreal: McGill University; p. 143.

Mabou FD, Tebou PLF, Ngnokam D, Harakat D, Voutquenne-Nazabadioko L. 2014. Leptocarposide: a new triterpenoid glycoside from Ludwigia leptocarpa (Onagraceae). Magn Reson Chem. 52:32-36.

Mohamed FA, Nabiel AM, Saleh SG, Ahmed MAE, Hani ES. 1983. Flavone glycosides of Salvia triloba. Phytochemistry. 22:2057-2060.

Ngbolua KN, Benamambote BM, Muanda DM, Ekutsu E, Tshibangu DST, Gbolo BZ, Muanyishay CL, Basosila NB, Bongo GN, Robijaona B. 2013. Ethno-botanical survey and ecological study of some 
medicinal plants species traditionally used in the district of Bas-Fleuve (Bas-Congo Province, Democratic Republic of Congo). Res J Chem. 1:1-10.

Okada H, Fukushi E, Yamamori A, Kawazoe N, Onodera S, Kawabata J, Shiomi N. 2010. Novel fructopyranose oligosaccharides isolated from fermented beverage of plant extract. Carbohydr Res. 345:414-418.

Sakan T, Murai F, Hayashi Y, Honda Y, Shono T, Nakajima M, Kato M. 1967. Structure and stereochemistry of boschniakine, boschnialactone, and boschnialinic acid, an oxidation product of boschnialactone. Tetrahedron. 23:4635-4652.

Sarkar R, Comment A, Vasos PR, Jannin S, Gruetter R, Bodenhausen G, Hall H, Kirik D, Denisov VP. 2009. Proton of ${ }^{15} \mathrm{~N}$-choline metabolites enhanced by dynamic nuclear polarization. J Am Chem Soc. 131:16014-16015.

Sisido K, Inomata K, Kageyema T, Utimoto K. 1968. Conformations of iridolactones and the stereochemistry in the syntheses. J Org Chem. 33:3149-3155.

Tanaka D, Yoshino T, Kouno I, Miyashita M, Irie H. 1993. Synthesis of monoterpene lactones, (+)-boschnialactone and (+)-isoiridomyrmecin, starting from L-(+)-arabinose. Tetrahedron. 49:1025310262.

Uesato S, Matsuda S, Inouye H. 1984. Mechanism for iridane skeleton formation from acyclic monoterpenes in the biosynthesis of secologanin and vindoline in Catharanthus roseus and Lonicera morrowii. Chem Pharm Bull. 32:1671-1674.

Uesato S, Matsuda S, lida A, Inouye H, Zenk MH. 1984. Intermediacy of 10-hydroxygeraniol, 10-hydroxynerol and iridodial in the biosynthesis of ajmaline and vomilenine in Rauwolfia serpentina suspension cultures. Chem Pharm Bull. 32:3764-3767.

Uesato S, Ueda S, Kobayashi K, Inouye H. 1983. Mechanism of iridane skeleton formation in the biosynthesis of iridoid glucosides in Gardenia jasminoides cell cultures. Chem Pharm Bull. 31:41854188.

Wang R, Paddon-Row MN, Sherburn MS. 2013. Short synthesis of 3-(hydroxymethyl)xylitol and structure revision of the anti-diabetic natural product from Casearia esculenta. Org Lett. 15:5610-5612.

Zhao Z, Matsunami K, Otsuka H, Shinzato T, Takeda Y. 2008. Tareciliosides A-G: cycloartane glycosides from leaves of Tarenna gracilipes (HAY.) OHWI. Chem Pharm Bull. 56:1153-1158. 